\title{
Early distance intervention and follow-up for families of infants and toddlers at risk for developmental disabilities and severe behavior problems in Peru
}

\author{
Rosa Oyama-Ganiko* \\ Liliana Mayo-Ortega** \\ Stephen R Schroeder*** \\ Judith M. LeBlanc****
}

\section{Abstract}

A major barrier to meeting the needs of low-income children and families with disabilities is distance from a center providing the diagnostics and treatment. In the U.S. several innovative ways of overcoming this difficulty have emerged, e.g. Call-In, Come-In Services in a Pediatric Psychology Practice, diagnostics and consultation via telemedicine, use of the Internet for webcasting conferences, library resources over the Internet, etc. These services are not yet available in many developing countries or in rural areas of the U.S., however. We report below an inexpensive and effective method of early distance intervention using workshops every two months and monthly telephone follow-up at the Centro Ann Sullivan del Peru in Lima, Peru. While many poor families may not have regular access to radio, television, or the Internet, we and others (Bigelow, Carta, \& LeFever, 2008) have found that almost all have cell phones, and they can be followed regularly. In our project on early prevention of severe aggression, self-injury, and stereotyped behavior among infants and toddlers at risk for developmental disabilities, monthly telephone follow-up attendance remained high throughout the one-year follow-up period (92\%), while family attendance at the six bi-monthly workshops dropped off (75\% to $28 \%$ ). Mean BPI frequency scores decreased significantly over the year. BPI scores were significantly higher, and they decreased more in the high-attendance group than in the low-attendance group. Family stress was reduced by $65 \%$. Consumer satisfaction was $98 \%$. A very similar workshop package has been given to many orphanages and to remote areas in Peru, where there is not any kind of education about disabilities and where parents have to be the best teachers. Having such tools gives them knowledge of what their children can achieve, so they would not relinquish them to government orphanages.

Keywords: Early distance intervention; Serious aggression; Autoaggression and stereotyped behavior; Infants and toddlers at risk; Workshops and follow-up by phone; Peru.

\footnotetext{
* Profesor Centro Ann Sullivan del Perú, CASP, San Miguel, Lima, Peru.

** Profesor Ph.D Fundadora \& Directora General - Centro Ann Sullivan del Perú- CASP, San Miguel, Lima, Perú.

*** Profesor Fundadora \& Directora General - Centro Ann Sullivan del Perú- CASP, San Miguel, Lima, Perú.

**** Profesor Fundadora \& Directora General - Centro Ann Sullivan del Perú- CASP, San Miguel, Lima, Perú.
} 


\title{
Intervenção precoce à distância e acompanhamento por familiares de crianças e bebês em situação de risco de problemas de desenvolvimento e de comportamento agressivo no Peru
}

\begin{abstract}
Resumo
A maior barreira para atender às necessidades de crianças com deficiência de baixa renda e suas famílias é a distância suas casas e um centro que ofereça diagnóstico e tratamento. Nos EUA várias maneiras inovadoras para superar essa dificuldade surgiram. Por exemplo, o Call-In, Come-In serviços em prática de Psicologia pediátrica, diagnóstico e consulta através de telemedicina, o uso da Internet para conferências, recursos de biblioteca através da Internet, etc. No entanto, estes serviços ainda não estão disponíveis em muitos países em desenvolvimento ou em áreas rurais os EUA. Apresentamos a seguir um método barato e eficaz de intervenção precoce à distância utilizando oficinas a cada dois meses e acompanhamento mensal por telefone no Centro Ann Sullivan do Peru, em Lima. Enquanto muitas famílias pobres não têm acesso regular à rádio, televisão ou da Internet, nós e outros (Bigelow, Carta, e LeFever, 2008) evidenciamos que quase todas as famílias têm telefones celulares, e elas podem ser acompanhados regularmente através dos mesmos. Em nosso projeto para prevenção precoce de agressão grave, autoagressão e comportamento estereotipado, entre as crianças e bebês em situação de risco de vir a apresentar um desenvolvimento atípico, o atendimento por telefone para acompanhamento mensal manteve-se em nível elevado durante todo o período de seguimento de um ano (92\%), enquanto atendimento às famílias nas seis oficinas bimestrais teve uma queda (de $75 \%$ para $28 \%$ ). Os escores médios de freqüência BPI diminuíram significativamente ao longo do ano. Pontuações BPI foram significativamente elevadas, e diminuíram mais no grupo de alta freqüência que no grupo de baixo comparecimento. Estresse familiar foi reduzido em $65 \%$ e a satisfação dos consumidores foi de $98 \%$. Um pacote de oficinas muito semelhante foi dado em diversos orfanatos de áreas remotas no Peru, onde não há qualquer tipo de educação sobre deficiência e onde os pais têm de ser os melhores professores. Ter essas ferramentas lhes dá conhecimento daquilo que os seus filhos podem alcançar, de modo que eles não venham a abandoná-los nos orfanatos do governo.
\end{abstract}

Palavras-chave: Intervenção precoce à distância; agressão grave; autoagressão e comportamento estereotipado; crianças e bebês em situação de risco de vir; oficinas e acompanhamento por telefone; Peru.

\section{Introduction}

A major barrier to meeting the needs of children and families with disabilities is distance from a center providing the diagnostics and treatment. In the 
U.S. several innovative ways of overcoming this difficulty have emerged, e.g. Call-In, Come-In Services in a Pediatric Psychology practice (Schroeder \& Gordon, 2002), diagnostics and consultation via telemedicine (Reese, et al., 2011), use of the internet for webcasting conferences and answering questions of parents, e.g. Elluminate Live!, (Cook, 2007) library resources over the Internet, e.g. General Disabilities Research Library (Minor,2005), Family Village website from the Waisman Center at the University of Wisconsin, etc. These services are not yet available in many developing countries, however. We report below an inexpensive and effective method of early distance intervention using workshops every two months and monthly telephone follow-up at the Centro Ann Sullivan del Peru in Lima. Peru. While many poor families may not have regular access to radio, television, or the Internet, we and others (Bigelow, Carta, \& Lefever, 2008) have found that almost all have cell phones, and they can be followed regularly.

\section{Methods}

Participants and Procedures

Screening. There were 262 families of infants and toddlers ranging in age from 4-48 mos. who were at risk for severe behavior problems and disabilities, who had been recruited via newspaper, television, and radio advertisements throughout Peru and screened for risk factors for aggression, self-injurious behavior, or stereotyped behavior. Details of the screening procedures and the risk algorithm can be found in Mayo, et al., (2012).

Interdisciplinary Evaluation. After screening, 233 children were given a very thorough interdisciplinary evaluation involving developmental pediatrics, genetics, ophthalmology, audiology, cognition, language/communication, and behavioral assessment, as well as neurological, psychiatric, and nutrition consultations, as needed. The main behavioral assessment instrument was the Behavior Problems Inventory (BPI-01, Rojahn, Matson, Lott, Esbensen, \& Smalls, 2001). They were then retested at six-month intervals for a year, while early intervention follow-up by the Center staff was occurring. Details of the interdisciplinary evaluations can be found in Schroeder, et al. (submitted). These evaluations were free, and were supported by a Fogarty International Research grant and by pro bono volunteer work of many professionals in Peru.

Early Intervention Follow-Up Procedures. Children's follow-up procedures consisted of two components: bi-monthly parent teaching workshops given at CASP and monthly telephone follow-up with each family by trained CASP staff over a twelve-month period. This was done to prevent drop-out from the study and to find the minimum, most cost-effective method of preventing serious behavior problems later in life. In all 180 families remained in the study for a year and had complete data sets. 
Six three-hour bi-monthly parent teaching workshops at the Center given by the Director (Dra. Mayo), entitled, "The ABCs of Treating Your Child with Different Abilities," covered a wide array of topics aimed at giving parents the first tools they needed that would permit them to be the best parent-teachers of their child and thus help them to begin their journey of becoming more independent, productive, and happy in life.

Table 1 - Topics of each workshop

Workshop 1

1. Parents are the best teachers of their children because they spend more time with their child.

2. Have high expectations of your children and include them in all activities of life.

2. Treat me as a person-Concentrate on what I can do, not on what I cannot do.

3. Goal for your child: Independent, productive and happy.

4. Tell your children "I love you" and be their friend.

5. Don't use verbal or physical punishment.

6 . Be sure to attend to your child's appropriate behaviors.

7. Be consistent in rules, expectations and consequences.

\section{Workshop 2}

1. Goal for child: independent, productive and happy

2. Always see their abilities rather than limitations

3. Give them chores at home.

4. Teach your child through modeling the behavior

5. Reinforce $t$ appropriate behavior.

6. Redirection

7. Consistency

8. Breathe

Workshop 3

1. Goal: independent, productive and happy.

2. Breathe

3. Be consistent in consequences for good and not so good behavior.

4. Identify a child's strengths and strengthen them with reinforcement

5. Talk more to your children. 
6. Tell them you love them.

7. Give them chores to do at home.

8. Teach them at every opportunity during family and community activities

9. How to handle aggression.

10.Teach child to accept changes

Workshop 4

1. Inclusion to life

2. Consistency and persistence

3. Increase communication

4. Redirection

5. Why to not use physical punishment?

6. What to do when you are angry?

7. Reminders to breathe, redirect, and leave the situation

8. Child's future independence and working depends on parents

9. Best teaching happens at home

\section{Workshop 5}

1. Take care of yourself as a person.

2. Involve all the family and teach them to be consistent

3. I am the best parent teacher for my child

4. High expectations: Independent, productive and happy

5. Given them chores, increase their self-esteem-Grandmother law

6. Tell your child "You can" and say to yourself "I can"

7. Am I raising my child to be a failure or a success? Things to do and not do

8. When give an instruction, be sure to follow up until the child complies.

9. Be selective about the behaviors to which I attend.

10. If angry, relax before disciplining your child. Don't lose control.

\section{Workshop 6}

1. Five food colors your child should eat

2. How children learn through observation

3. Importance of exercises

4. Chores: Responsibilities in the house 
5. High expectations: Independent, productive and happy.

6. Communication

7. Be consistent in reinforcing and correcting behaviors

8. When frustrated breath, redirect and/or leave the room or situation.

9. Importance of constant communication between you and CASP

Topics for the first two workshops were selected from information collected on each child at their screening interview on the Parental Concerns Questionnaire (Mayo, et al. 2012). Topics for the four subsequent workshops were selected by analyzing the data of the telephone follow-ups and information provided by the specialists who analyzed the data of the first workshops to identify areas in which the parents needed more training. The information of the telephone follow-up was crucial for developing the workshops.

The main topics of the six workshops were divided into six categories: (1) adaptive behaviors, i.e. independence, communication, following instructions, and doing chores at home; (2) the behaviors the parents indicated they most wanted to learn, i.e. how to teach their child to communicate, to follow instructions, to deal with tantrums and aggression towards others; (3) parental behaviors to work more effectively with their child, i.e. detecting the abilities of their child, identifying and reinforcing the adaptive behaviors of their child; (4) ignoring (as much as possible) their child's disruptive behaviors and redirecting them to more adaptive behaviors;(5) taking deep breaths and waiting a moment before responding to child when stressed; (6) consistency in providing feed back to their child.

After each workshop, parents completed a survey suggesting topics for which they wanted more information. Parent participation in the selection of topics for their workshops improves their motivation to maintain what they have learned (Mayo \& LeBlanc, 2003).

Training sequences that were followed in the workshops were: (1) parents signed an attendance sheet; (2) a lecture with ongoing discussion with the parents was given; (3) parents practiced and role-played what was being taught; (4) parents were encouraged to practice their new skills in their daily routines at home and in the community;(5) parents were encouraged to teach members of the family what they had learned in the most recent workshop session.

Teaching approaches used in workshops were interactive between parents and the lecturer and between parents and other parents, sharing child problems and solutions. The instructional packages included lectures, written instructions, and videotapes of appropriate and inappropriate behavior management, and how to teach functional skills. 
Current adult students enrolled in Centro Ann Sullivan del Peru-CASP gave presentations, explaining in each session what they did in their real jobs. Parents with their children from CASP demonstrated how they taught their child to do chores at home, to eat, and to dress, etc. Videos were also shown of CASP students in their communities, homes, and businesses. Demonstrations were also given with children who attended the workshops with their parents and who were not following the parent's instructions. The lecturer or other CASP staff immediately went to the child and demonstrated how to instruct, so that child compliance was achieved. Printed key points of topics were provided after each workshop to the parents to take home as reminders of what they learned at the conclusion of each workshop.

The other component of follow-up was monthly scripted telephone followup calls to parents, lasting c.15-20 minutes each, by 15 CASP Center Specialists, trained by Dra. Oyama, in which they asked a series of leading questions of the parents and provided suggestions, if asked, on how to handle difficult situations with their child.

The telephone follow-up to parents was a strategy with five purposes: (1) To gather information regarding the developmental advances or no progress of the children's behaviors and their abilities, as well as their overall health and other worries parents might have about their children during the study; (2) to give suggestions, without direct intervention with children and/or parents, even though some might be receiving individual therapies or education in other educational centers; (3) to gather data useful as reference to determine topics of interest for the six workshops offered by Dra. Mayo; (4) and to maintain parents' motivation to stay in the study; (5) and to experience the application of CASP's Natural Functional Curriculum (NFC, Mayo \& Leblanc, 2003). Parents were asked for their different dates and schedules that were most convenient for them for the follow-up to be done.

Format design used for telephone follow-up was: (1) general information: (a) name and code of the child, name of interviewer, date of phone follow-up, name of interviewee and child relationship;(b) a short script, so the specialist can introduce him/herself properly and then the phone follow-up begins; (c) six open response items for the family member that included: things the child has improved since his/ her participation in the study; behavior concerns (is he/she better/worse); eating and sleeping behavior issues; health issues; attendance to therapy, nursery; other concerns. The information given by the parents was useful to consider the topics for the ABC workshops; (2) items for which parents requested advice and comment by the CASP Specialist.

Training of the 15 CASP Specialists to do the Telephone Follow-Up effectively within 15-20 minutes in each call, consisted of the following information: (a.) explaining the reason for the follow-up to families that participated in the Study; (b.) how to do the file checkup of each child to obtain specific information about their medical history, applied exams, information given by parents; (c.) how to present themselves before the parents and to begin with the Follow-Up protocol; (d.) how 
to write in the Follow-Up Form the data given in a brief manner during the same interview; (e.) the Importance of handing in to the Data Coordinator at the end of each Follow-Up, the Form with complete information for its tabulation and analysis; (f.) the files of each child could only be revised inside the Projects \& Research Area of the Center, to maintain privacy; (g.) these telephone calls would be done using CASP Office phones or cell phones only; (h.) each month, CASP Specialists would receive a printed list with the children who were continuing in the Study, their phone numbers, and the days and schedules suggested by the parents to be contacted by them; (i.) if parents could not be reached to do the monthly follow-up, each failure to contact (day and time) was registered in the corresponding child's Follow-Up form. Training consisted of Real-Life demonstration, role playing, individual and group practice and follow-up.

\section{Results}

Of the 262 families admitted to the study, 233 enrolled, and 180(69\%) completed all three interdisciplinary evaluations over the 12 -month period. The majority were evenly distributed over the low-through-upper-middle income classes, and they had elementary, high school, college, or post-graduate educations. Very few were indigent or very wealthy. Drop-out resulted for a wide variety of reasons unrelated to the follow-up training, e.g. child illness or death, mother's additional child birth, moving from the area, parents' work schedules, long travel distance to the Center for evaluations and parent training, etc.

\section{Workshop Effects}

Attendance of families at each of the six workshops began with $176(75 \%)$ attendees at the first workshop and declined with each subsequent one to $46 \%, 30 \%$, $26 \%, 28 \%$, and $28 \%$ respectively. Parents and other family members also attended. The attendance included $62 \%$ mothers and $25 \%$ fathers. To assess the effects of workshop training on the children's behavior, a repeated measures factorial ANOVA, comparing the effects of high-attendance ( 5 or 6 workshops, $N=21$ ) vs. low-attendance ( 0 or 1 workshop, $\mathrm{N}=52$ ) across the three interdisciplinary evaluation times on the children's BPI Total frequency scores and those for each subscale, i.e. SIB, Aggression and Stereotyped Behavior. The children of the High-Attendance group had higher BPI Total Frequency scores than the Low-Attendance group, $F(1,71)=9.64 . p=.003$, and they decreased more over the three time periods, although this interaction effect failed to reach significance, $F(2,70)=1.54, p=.22)$. Figure 1 illustrates this effect. The overall effect across the three evaluation periods, however, was significant, $F(2,70)=4.49$ $\mathrm{p}=.015$.

After every workshop, the parents evaluated the usefulness of the content and their active participation in the workshop, e.g. they observed that their children played more, followed instructions, learned more words and learned more behaviors and they would like more instruction. The average evaluations of the 6 workshops were. Excellent 65\%. Very Good 33\% and Good 1\%. 


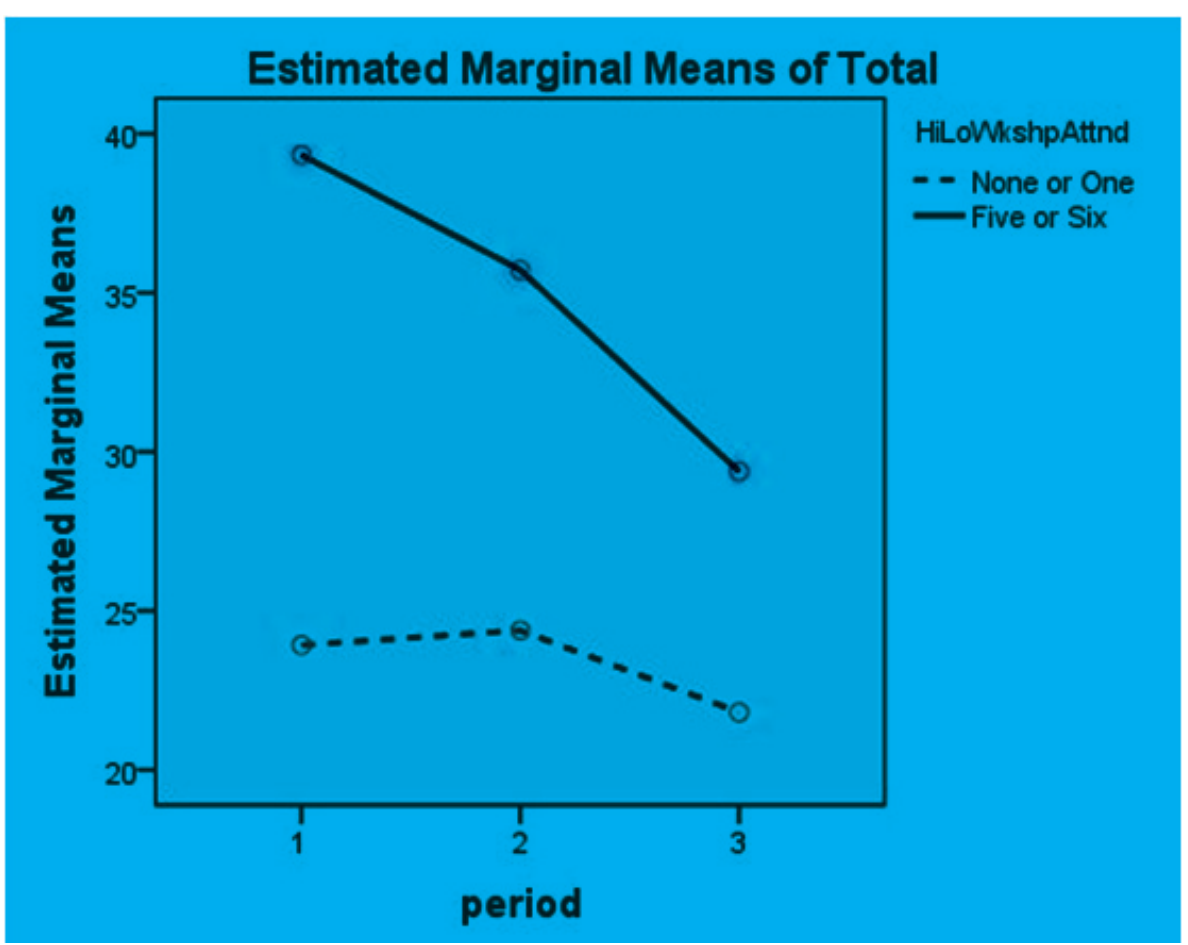

Fig. 1 - BPI Total Frequency for the Low-vs. High Workshop Attendance Groups across Evaluation Times 1,23

In the fifth session, parents were surveyed about their levels of stress before and after the workshops on a scale from 1 to 10. The majority of the parents indicated, on average, over $25 \%$ less stress after attending the workshops.

In general, the parents reported that their children improved in their behavior, their communication, and they paid more attention. Their descriptions of the improved behaviors included: "(l) turns to or looks at the person who calls him by his name;(2) when spoken to, he looks at the person and does what is asked to do, even if it is with help;(3) he understands more about what it is being said; (4) he is more alert to what happens around him." Examples were: "(l) before, he only just paid attention to what was he doing, but now if he is playing, and, if somebody enters the room (for instance, his father), he turns around to look and see who has come in;(2) he is more alert to other peoples' conversations. For instance, when parents are talking between themselves and say 'Later we'll go out', the child hears this and goes to the door as if to go out with them, or goes to his room and puts on his shoes;(3) he looks where they have put away what he likes; (4) he plays better with his siblings, or with other children or adults, even when the games are new to him, as opposed to those usually played with him;(5) if he is playing and somebody calls him, he turns around to see who has called; (6) he looks at figures 
and signs that before did not call his attention; (7) he plays more appropriately with toys rather than just hitting or knocking them around. He attends more to detail and makes them function as intended." These were all advances considered vital for the children's future developmental learning.

\section{Telephone Follow-up Effects}

In contrast to workshop attendance, attendance to telephone follow-ups was very high, both for those who completed all of the interdisciplinary evaluations (92\%), as well as for those who did not complete all of the evaluations $(81 \%)$.The number of parents reporting improvements of their child at home after Telephone Follow-up is shown in Table 2

Table 2 - Number of Parents Reporting Child Improvement after Telephone

Follow-Ups

\begin{tabular}{|c|c|c|c|c|}
\hline $\begin{array}{c}\text { Months Phone } \\
\text { Follow-Ups }\end{array}$ & $\begin{array}{c}\text { Tot. phone } \\
\text { follow-up }\end{array}$ & $\begin{array}{c}\text { Improved } \\
\text { reported }\end{array}$ & No changes & No responses \\
\hline Dec 2010 & 215 & 208 & 6 & 1 \\
\hline Jan 2011 & 212 & 208 & 4 & 0 \\
\hline Feb 2011 & 205 & 202 & 3 & 0 \\
\hline Ma 2011 & 205 & 201 & 3 & 1 \\
\hline May 2011 & 202 & 198 & 5 & 1 \\
\hline Jun 2011 & 192 & 187 & 3 & 0 \\
\hline Aug 2011 & 193 & 190 & 10 & 0 \\
\hline Sept 2011 & 193 & 183 & 3 & 2 \\
\hline Nov 2011 & 176 & 171 & 5 & 2 \\
\hline Jan 2012 & 140 & 133 & 3 \\
\hline
\end{tabular}

A summary of specific parental responses to specific telephone questions is given in Table 3 . 
Table 3 - Percentage of parents responses to casp staff questions at telephone follow-up at the first call and the last call (call no. 9)

\section{First Call}

Child Improvements (\%)

More Positive Behaviors

Pays Attention

Follows Instructions

Communicates More

More Loving

Eating More

Exercising more

Fewer Negative Behaviors

Aggression

Self-Injurious Behavior

Stereotyped Behaviors

Tantrums

Highest Parental Concerns

Aggression

Self-Injurious Behavior

Stereotyped Behaviors

Tantrums

Destruction of Objects

Fails to Follow Instructions

Lack of Communication

Phobias

Other Concerns
47

29

64

4

8

9

13

10

4

5

31

12

12

38

10

16

26

2

70

\section{Last Call}

49

64

7

18

24

6

6

3

16

13

14

10

28

1

11

5

3

29 


\section{Other Health Indicators}

\begin{tabular}{lcc} 
Sleeping Better & 59 & 70 \\
Eating Well & 53 & 83 \\
General Health & 59 & 70 \\
Daily Programmed Activities & & \\
Nursery & 43 & 43 \\
Language Therapy & 35 & 30 \\
Physical Therapy & 23 & 28 \\
None & 30 & 16 \\
\hline
\end{tabular}

These parents' responses corresponded closely to the results of the independent structured interviews concerning the children's severe problem behaviors on the Behavior Problems Inventory (Rojahn, et al., 2001) at the time of the in-depth interdisciplinary evaluation (Mayo, et. al, 2012; Schroeder, et al., submitted). Most of the negative behaviors improved in the desired direction, although many parents still had concerns at the end of one year in the study. The workshops and telephone suggestions helped them substantially in their confidence in managing their child and in coping with their stress, as shown in Table 4, where fewer suggestions by the CASP consultant were needed at the end of the 12 -month period.

Table 4 - percentage of parents given suggestions at telephone follow-up. Calls at the first and last calls (call no 9).

\begin{tabular}{lll} 
& First Call & Last call \\
\hline 1. Give him more support activities to do & 54 & 37 \\
2. Redirect him/her & 72 & 55 \\
3. Give him/her tasks to do & 68 & 18 \\
4. Congratulate/reinforce him/her & 18 & 65 \\
5. Teach him/her to eat & 20 & 3 \\
6. Take a deep breath and persist & 5 & 31 \\
7. Do exercises & 9 & 3 \\
8. Continue therapies & 8 & 3 \\
\hline
\end{tabular}




\section{Social Validation}

During the third evaluation of children, parents completed a Survey concerning their opinions about what helped them most to educate their child during this study. $70 \%$ responded that both the Workshops, as well as the Monthly Follow-Up Phone Calls, helped them.

\section{Discussion}

The combination of parent training workshops linked to telephone followup was successful in reducing severe behavior problems of infants and toddlers living in low-to-middle income families in Peru. Declining attendance at the six workshops reflects the difficulties families had in attending center-based training, while the telephone follow-up attendance remained high throughout the year in the study. Their combination appeared to help in preventing drop-out, which is often a serious problem in such studies.

A unique feature of the training was the joint decision making by the parents and CASP staff in choosing topics and requesting information, which is characteristic of CASP's life span approach to inclusion (LeBlanc, Schroeder, \& Mayo, 1996; Mayo \& LeBlanc, 2003). Full inclusion of the parents, siblings, and other members of a household is a likely factor in success of their train-the-trainer model and, of their consumer satisfaction, and of their retention of what was trained.

There are few parent training programs for families of infants and toddlers with DD and severe behavior problems (see Richman, 2008; Schroeder \& Courtemanche, 2012 for reviews). The present program is a beginning step in that direction.

Limitations of the Study. It has certain limitations in that there was not a randomized controlled clinical trial with a control group. The parents, however, refused to be part of a wait list because many felt they were in crisis with their children. CASP staff, therefore, had ethical concerns about withholding treatment completely. Another limitation was that the training program was not manualized. We intend to write a manual, once the program has been finalized. Many of the parents and other family members had limited literacy. The lecture, demonstration, role play strategy appeared more appropriate for them, so that all family members were included in the training. Although preliminary, this approach seems promising for future randomized controlled studies of parent training of families who have very young children with DD and severe behavior problems and who live at a distance from their training center.

A very similar workshop package as the above one has been given successfully by CASP to many orphanages and to organizations in remote areas in Peru, e.g. the jungle, where there is not any kind of education about disabilities and where parents have to be the best teachers of their children. Having such tools gives 
them knowledge of what their children can achieve, so they would not relinquish them to government orphanages. In Peru, as in many developing countries, these institutions are mostly custodial, and they provide few education or habilitation programs for children.

\section{References}

BIGELOW, K. M., CARTA, J. J.; LEFEVER, J. B. Using cellular phone technology to enhance a parent intervention for families at risk for neglect. Child Maltreatment, v. 13, p.362-367, 2008.

COOK, T. Appropriate information-communications technologies for developing Countries. Bulletin of the World Health Organization, v. 85, p. 245-324, 2007.

LEBLANC, J. M.; SCHROEDER, S. R.; MAYO, L. A Life Span Approach in the Education and Treatment of Persons with Autism. In Cohen, D. \& Volkmar, F.R. (Eds). Handbook of Autism and Pervasive Developmental Disorders, Second Edition. New York: Wiley Publishing. U.S.A, 1996.

MAYO-ORTEGA, L.; LeBlanc, J. M. Inclusion across the life span for people with different abilities. In Timmins, \& Walsh, P. Eds. A Long Walk to School, Global Perspectives on Inclusive Education. Rotterdam/Boston/Taipei: Sense Publishers, 2003, p. 27-39.

MAYO-ORTEGA, L;; OYAMA-GANIKO, R.; LEBLANC, J.; SCHROEDER, S. R.; BRADY, N.; et al. Mass screening for severe problem behavior among infants and toddlers in Peru. Journal of Mental Health Research in Intellectual Disabilities, v. 5, p. 246-259, 2012.

MINOR, E. Internet in a box: Augmenting bandwidth with eGranary Digital Library. Africa Today, 52, Special Issue: African Electronic Publishing, 2005.

REESE, R. M.; JAMISON, T. R.; WENDLAND, M.; FLEMING, K.; BRAUN, M.; TUREK, J. Evaluating interactive vidoeoconferencing for assessing symptoms of autism, 2012, submitted.

RICHMAN, D. M. Early intervention and prevention of self-injurious behavior exhibited by young children with developmental disabilities. Journal of Intellectual Disability Research, v. 52,2008, p. 3-17.

ROJAHN, J.; MATSON, J. L.; LOTT, D.; ESBENSEN, A. J.; SMALLS, Y. The Behavior Problems Inventory: An instrument for assessment of self-injury, stereotyped behavior, and aggression/destruction in individuals with developmental disabilities. Journal of Autism and Developmental Disorders, v. 31, p. 577-588, 2001.

SCHROEDER, C. S.; GORDON, B. N. Assessment \& treatment of childhood behavior problems. 2nd edition. New York: Guilford Press, 2002.

SCHROEDER, S. R.; COURTEMANCHE, A. B. Early prevention of severe neurodevelopmental behavior disorders: A integration. Journal of Mental Health Research in Intellectual Disabilities, v. 5, p. 203-214, 2012.

SCHROEDER, S. R.; MARQUIS, J. M.; REESE, R. M.; RICHMAN, D. M.; MAYO-ORTEGA, L.; et al. Risk factors for self-injury, aggression, and stereotyped behavior among infants and toddlers at risk for developmental disabilities, 2012, submitted. 


\section{Correspondência}

Rosa Oyama-Ganiko - Centro Ann Sullivan del Perú-CASP, Calle Petronila Alvarez 180-Urb Pando San Miguel, Lima 32, Perú.

E-mail: rosao@annsullivanperu.org - lilimayo@annsullivanperu.org - leblanc@ku.edu

Recebido em 27 de abril de 2013

Aprovado em 18 de julho de 2013 
